\title{
A comparison between the body composition, carcass characteristics and retail cuts of South African Mutton Merino and Dormer sheep
}

\author{
J.J.E. Cloete ${ }^{1,2}$, L.C. Hoffman ${ }^{1 \#}$, S.W.P. Cloete ${ }^{1,3}$ and J.E. Fourie ${ }^{3}$ \\ ${ }^{1}$ Department of Animal Sciences, University of Stellenbosch, Private Bag X1, Matieland 7602, South Africa \\ ${ }^{2}$ Elsenburg College of Agriculture, Private Bag X1, Elsenburg 7607, South Africa \\ ${ }^{3}$ Elsenburg Agricultural Development Institute, Private Bag X1, Elsenburg 7607, South Africa
}

\begin{abstract}
The body composition, carcass characteristics and retail cuts of 61 Dormers (21 rams and 40 ewes) and 35 South African Mutton Merinos (SAMM) (17 rams and 18 ewes) were determined. A range of carcass measurements was recorded. Since there was no sex x breed interaction, only main effects of breed and sex were considered. There were no differences in slaughter weight between Dormer and SAMM sheep at 18 months of age. Dormers had a 2.7\% point higher dressing percentage and a $6.2 \%$ higher carcass weight than the SAMM. The Dormer had a higher fat content (kidney fat, back-fat depth) than the SAMM. The eyemuscle area of the Dormers was 13\% larger than that of the SAMM sheep. Rams were heavier than the ewes at slaughter. All the traits measured, indicated advantages in favour of rams. Only the saturated, monounsaturated fatty acids and polyunsaturated fatty acids to saturated fatty acids ratio differed significantly between the Dormer and SAMM sheep. Based on the fatty acid profile, SAMM meat is slightly healthier than that of Dormer sheep. The higher retail cut weights of Dormers suggested that they were superior to the SAMM as far as meat production was concerned.
\end{abstract}

Keywords: Carcass, Dormer, meat yield, muscle composition, SAMM, sex

\# Corresponding author. E-mail: lch@sun.ac.za

\section{Introduction}

The South African Mutton Merino (SAMM) is a dual-purpose (mutton and wool) sheep breed, which was developed from the imported German Merino breed. The breed has a high growth rate and produces a slaughter lamb with good meat quality attributes (Neser et al., 2000). The Dormer is a breed that was developed at Elsenburg experimental farm from the Dorset Horn and the former German Merino breeds. The principal objective in developing the Dormer was to provide a terminal sire breed for crossbreeding on Merino ewes (Van der Merwe, 1976). The Dormer is an early-maturing breed and tends to deposit fat early, while the SAMM is a late-maturing breed that deposits fat at a later age (Neser et al., 2000). When lambs are slaughtered at the same age, the SAMM should have less fat than the early-maturing Dormer.

Carcasses of meat animals are composed primarily of varying proportions of muscle, fat and bone. In developed countries where an overabundance of kilojoules is commonly found, muscle, and not fat, is the most important carcass tissue to the consumer. Certain muscles, such as those of the hind leg and loin, contribute to the higher-priced cuts of the carcass, because they contain less associated fat and connective tissue (Thonney et al., 1987). For this reason differences between breeds in the degrees of maturity and the distribution of muscle are commercially important.

The effects of breed, age and live weight on the carcass composition and retail cuts of meat-type lambs have been studied in detail (Hopkins et al., 1992). Jeremiah et al. (1997) found that at the same age, rams were more developed in the neck and head area than ewes, while ewes were more developed in the hindquarters (Fahmy et al., 1999). Despite the difference in growth rate, rams yielded lower carcass weights than ewes at an equal slaughter weight as a result of a greater head weight and the weight of the testicles (Purchas, 1978). Rams deposited less total carcass fat and have smaller individual fat depots than ewes at the same age (Kirton et al., 1995).

Research has been conducted on slaughter traits of the SAMM breed (Casey, 1982; Webb \& Casey, 1995), but no results pertaining to comparative slaughter traits in these two breeds could be found in the literature. This paper examines the effect of breed and sex on the body composition, carcass characteristics and retail cuts of the meat from SAMM and Dormer sheep. 


\section{Materials and Methods}

Data were obtained from 61 (21 rams and 40 ewes) 18-month old Dormer and 35 (17 rams and 18 ewes) 18-month old SAMM sheep reared at Elsenburg experimental farm. All these sheep were not selected as replacements for breeding purposes in their flocks of origin. Ewes and rams of both breeds were maintained in the same flocks, separated on gender from weaning until slaughter. Both groups utilised mainly kikuyu (Pennisetum clandestinum) pastures, but the rams received supplemental concentrates and lucerne hay before being subjected to breed inspection in May - June. Both groups were subjected to the same level of husbandry (e.g. parasite control). A drenching and inoculation programme as prescribed by the state veterinarian was followed (Van Wyk et al., 1993).

Fasted live weight was determined 24 hours prior to slaughter. The sheep were slaughtered at a commercial abattoir using standard South African techniques. After being electrically stunned (4 seconds at 200 volts) the sheep were exsanguinated and the carcasses suspended to bleed. After dressing, the carcasses were suspended in a cooler at $2{ }^{\circ} \mathrm{C}$ for 48 hours. No electrical stimulation was applied.

Recordings on the carcass included the weight of carcass components and offals, cold carcass weight (after 24 hours in a cooler at $2{ }^{\circ} \mathrm{C}$ ), the weight of different retail cuts and back-fat depth. The latter was measured at a site $25 \mathrm{~mm}$ off the midline at the $13^{\text {th }}$ rib (Gilmour et al., 1994). The thickness of the skin was measured at the same site as back-fat depth. Carcass length was measured on the suspending carcass from the pubis bone to the cranial edge of the first rib. The leg circumference was measured at two points: the first leg circumference (1) was taken at the maximum circumference of a line passing over the distal end of the iliac wings of the pelvis and the most caudal point on the median line between the legs (Stanford et al., 1997), and the second leg circumference (2) was taken at the stifle (Oman et al., 1999). Hind leg length was measured from the inner edge of the proximal end of the tibia to the anterior tip of the pubis (Enright, 1990). The carcass depth was measured at the first rib posterior of the sternum, and the carcass width was taken at the widest place of the carcass. The eye-muscle area was also measured at the $13^{\text {th }}$ rib (Gilmour et al., 1994) by tracing the eye-muscle circumference onto wax paper. The silhouette of the eye-muscle was then passed through a Li Cor LI3100 (1 $\mathrm{mm}^{2}$ resolution) for determination of surface area. Each silhouette was measured in five fold and the mean used in the statistical analysis.

After 48 hours in the cooler the carcasses were partitioned into South African retail cuts, which were weighed separately. These cuts consisted of the neck, shoulder, chuck, flat rib, prime rib, loin and hindquarters. The neck was removed at the seventh cervical vertebrae (the point where the neck starts bending), the cut being made at a right angle to the spine. Thereafter the hind legs were removed. This consisted of loosening the flanks on the inside of the legs (following the curve of the leg muscle) to an imaginary line perpendicular to the ilium (seen from the inside of the carcass). Both legs were then removed by cutting along this line, just missing the ilium (through the last lumbar vertebrae). The rest of the carcass was then halved prior to being separated into trade retail cuts. Both shoulders were removed by sawing along an imaginary line from the elbow joint to a point below the spinal column, between the fifth and sixth ribs. The carcass was then swivelled so that the spinal column was sawn through at right angles. The flank was removed by sawing from the M. obliquus abdominis internus parallel to the spine. The loin and rib were separated perpendicularly to the spinal column at the junction of the thoracic and lumbar vertebrae (Hoffman, 2000). All commercial cuts were weighed on a digital computing scale, which measures to the nearest gram.

The $11 / 13^{\text {th }}$-rib cuts from the right side of the carcass from 24 SAMM (12 rams and 12 ewes) and 24 Dormer (12 rams and 12 ewes) carcasses selected at random, were removed. The deviation from the standard site was required by the abattoir. The M. longissimus dorsi was dissected (without subcutaneous fat), minced, freeze dried and analysed for proximate chemical composition as follows: the protein by a FP428 Nitrogen and Protein Determinator (Leco). Lipids (petroleum ether extraction) were measured according to ALASA (1995). Moisture and ash contents were determined by drying samples ( $\pm 1.0 \mathrm{~g})$ at 100 ${ }^{\circ} \mathrm{C}$ to a constant weight (moisture) prior to ashing at $500{ }^{\circ} \mathrm{C}$ overnight (ALASA, 1995).

The remaining meat from the M. longissimus dorsi was used for fatty acid analyses. Fatty acid methyl esters (FAME) were prepared from the total lipids according to the method of Morrison \& Smith (1964). The FAME were analysed with a GLC: Varian Model 3300, equipped with a flame ionisation detector and two $30 \mathrm{~m}$ fused silica megabore DB-225 columns of $0.53 \mathrm{~mm}$ internal diameter (J\&W Scientific Folsom, CA). Gas flow rates were: hydrogen, $25 \mathrm{~mL} / \mathrm{min}$; air, $250 \mathrm{~mL} / \mathrm{min}$; and nitrogen (carrier gas), 5-8 $\mathrm{mL} / \mathrm{min}$. Temperature programming was linear at $4{ }^{\circ} \mathrm{C} / \mathrm{min}$; initial temperature, $160{ }^{\circ} \mathrm{C}$; final temperature, $220{ }^{\circ} \mathrm{C}$ held for $10 \mathrm{~min}$; injector temperature, $240{ }^{\circ} \mathrm{C}$; and detector temperature, $250{ }^{\circ} \mathrm{C}$. The FAME were 
identified by comparison of the retention times to that of a standard FAME mixture (Nu-Chek-Prep Inc., Elysian, Minnesota). The saturated fatty acids (SFA), mono-unsaturated fatty acid (MUFA) and polyunsaturated fatty acid (PUFA) were all calculated. The PUFA:SFA ratio, desirable fatty acid (DFA) and the ratio of (C18:0=C18:1n9):C16:0 were also calculated (Rhee, 1992).

Prior to testing for differences of the various parameters between the two breeds and sexes, a least square analysis of variance was done according to a 2 (breed, SAMM and Dormer) x 2 (sex, male and female) factorial design to account for uneven subclasses. Least squares methods have been successfully used over the past few decades for the analysis of unbalanced designs in animal breeding experiments (Harvey, 1982). Line did not interact $(\mathrm{P}<0.05)$ with sex for any of the traits, and results pertinent to the interaction were thus not presented. The ASREML programme was used to obtain the relevant least squares means (Gilmour et al., 1999). This software enables the estimation of various random and fixed effects and the prediction of least squares means for various fixed and interaction effects in animal breeding experiments. The differences between treatment means for the two breeds and between sexes were then tested separately by means of the null hypothesis $\left(\mathrm{H}_{0}\right)$ with $\mathrm{H}_{0}: \mu=\mu_{\mathrm{o}}$ and the alternative hypothesis $\left(\mathrm{H}_{\mu}\right)$ being $H_{\mu} ; \mu \neq \mu_{0}$. This was done by means of contrast analysis and estimated least square means ( \pm s.e.) as reported in the tables. Differences between the variables were accepted as being significant if the possibility of rejection of $\mathrm{H}_{0}$ was equal to or less than $5 \%(\mathrm{P} \leq 0.05)$.

\section{Results}

Since there was no sex and breed interaction, least square means depicting the main effects of breed and sex were tabulated. The means ( \pm s.e.) of the various parameters measured are shown in Table 1. Although there was no difference in mean slaughter weight between the two breeds, the Dormers had a 2.7 percentage point higher $(\mathrm{P}<0.01)$ dressing yield, which resulted in a $6.2 \%$ higher $(\mathrm{P}<0.05)$ carcass weight.

The mean skin weight of SAMM sheep was heavier $(\mathrm{P}<0.01)$ than that of the Dormers. Similarly, the trotters of SAMM sheep were $5 \%$ heavier $(\mathrm{P}<0.01)$ than those of Dormers. The mean carcass $(\mathrm{P}<0.05)$ and hind leg length $(\mathrm{P}<0.01)$ of SAMM sheep were longer than those of Dormers. Dormers had a greater mean carcass width $(\mathrm{P}<0.01)$ than their SAMM contemporaries. The kidneys of the SAMM sheep were heavier $(\mathrm{P}<0.01)$ than those of Dormers, but the livers of Dormers were heavier $(\mathrm{P}<0.05)$ than those of SAMM sheep. The kidney fat weight $(\mathrm{P}<0.05)$ and fat depth $(\mathrm{P}<0.01)$ of the Dormer sheep were respectively heavier and thicker than those of SAMM sheep. Mean shoulder, flat rib and loin retail cut weights were generally higher in Dormers than in SAMM sheep. The mean eye-muscle area of the Dormers was $13 \%$ larger $(\mathrm{P}<0.01)$ than that of SAMM sheep (Table 1$)$. This result is consistent with the assumption of the Dormer being an earlier maturing type, as also indicated by thicker fat depth.

The mean slaughter weight of the rams (pooled breeds) was $45 \%$ heavier $(\mathrm{P}<0.01)$ than that of the ewes. A corresponding difference $(\mathrm{P}<0.01)$ of $44 \%$ was found for carcass weight between sexes, but there was no effect of sex on dressing percentage. In almost all the other traits mentioned in Table 1 means for rams were higher $(\mathrm{P}<0.01)$ than those of ewes. No sex difference was observed in two traits only, namely the kidney fat weight and fat depth $25 \mathrm{~mm}$ from the midline at the $13^{\text {th }}$ rib (Table 1).

There were no differences between the mean proximate chemical composition of the $11 / 13^{\text {th }}$-rib cut (M. longissimus thoracis) of SAMM and Dormer sheep (Table 2). The protein $(\mathrm{P}<0.05)$, lipid $(\mathrm{P}<0.05)$ and ash $(\mathrm{P}<0.01)$ content of meat from ewes were higher than those of rams (Table 2).

As there was no sex $\mathrm{x}$ breed interaction effect on the fatty acid composition of the M. longissimus thoracis, the data were only tested for breed and sex main effects. There were only a few differences in the fatty acid composition between SAMM and Dormer sheep and the rams and ewes (Table 3). The two most prominent SFA were palmitic acid (C16:0) and stearic acid (C18:0). There were significant differences in myristic acid (C14: 0) $(\mathrm{P}<0.01)$, arachidic acid (C20:0) $(\mathrm{P}<0.01)$ and total SFA $(\mathrm{P}<0.01)$ concentrations between breeds. Oleic acid (C18:1n9) was the most prominent MUFA, whilst linoleic acid (C18:2n6) was the most prominent PUFA. The MUFA differed significantly between the breeds but not between sexes. There was a significant difference between breeds and sexes for the ratio of PUFA:SFA. Desirable fatty acid and the ratio of (C18:0=C18:1n9):C16:0 did not differ between breeds or sexes. 
Table 1 Least square mean ( \pm s.e.) of body composition, carcass characteristics and retail cuts yields for the main effects of breed (SAMM vs. Dormer) and gender (ram vs. ewes)

\begin{tabular}{|c|c|c|c|c|}
\hline \multirow[b]{2}{*}{ Trait } & \multicolumn{2}{|c|}{ Breed } & \multicolumn{2}{|c|}{ Sex } \\
\hline & $\begin{array}{l}\text { SAMM } \\
(\mathrm{n}=35)\end{array}$ & $\begin{array}{l}\text { Dormer } \\
(\mathrm{n}=61)\end{array}$ & $\begin{array}{c}\text { Ram } \\
(\mathrm{n}=38)\end{array}$ & $\begin{array}{c}\text { Ewes } \\
(\mathrm{n}=58)\end{array}$ \\
\hline \multicolumn{5}{|l|}{ Carcass characteristics } \\
\hline Slaughter weight (kg) & $54.2 \pm 0.9$ & $55.2 \pm 0.7$ & $64.9 \pm 0.9^{\mathrm{a}}$ & $44.6 \pm 0.7^{\mathrm{b}}$ \\
\hline Carcass weight (kg) & $21.7 \pm 0.2^{\mathrm{a}}$ & $23.2 \pm 0.4^{b}$ & $27.8 \pm 0.5^{\mathrm{a}}$ & $19.25 \pm 0.43^{b}$ \\
\hline Dressing \% & $41.5 \pm 0.4^{\mathrm{a}}$ & $44.2 \pm 0.3^{\mathrm{b}}$ & $42.7 \pm 0.4$ & $43.1 \pm 0.3$ \\
\hline Skin weight (kg) & $4.99 \pm 0.10^{\mathrm{a}}$ & $4.17 \pm 0.08^{b}$ & $5.52 \pm 0.09^{a}$ & $3.64 \pm 0.08^{b}$ \\
\hline Skin thickness (kg) & $2.22 \pm 0.05$ & $2.20 \pm 0.04$ & $2.38 \pm 0.05^{\mathrm{a}}$ & $2.04 \pm 0.04^{b}$ \\
\hline Head (kg) & $3.05 \pm 0.04^{\mathrm{a}}$ & $2.88 \pm 0.03^{b}$ & $3.51 \pm 0.04^{\mathrm{a}}$ & $2.42 \pm 0.03^{b}$ \\
\hline Trotters (kg) & $1.17 \pm 0.02^{\mathrm{a}}$ & $1.11 \pm 0.12^{b}$ & $1.34 \pm 0.02^{\mathrm{a}}$ & $0.94 \pm 0.01^{b}$ \\
\hline Testes (kg) & $0.62 \pm 0.03$ & $0.58 \pm 0.02$ & & \\
\hline Carcass length $(\mathrm{cm})$ & $78.0 \pm 0.5^{c}$ & $77.5 \pm 0.4^{\mathrm{d}}$ & $80.5 \pm 0.5^{\mathrm{a}}$ & $75.0 \pm 0.4^{\mathrm{b}}$ \\
\hline Carcass depth (cm) & $30.6 \pm 0.2$ & $30.7 \pm 0.2$ & $32.3 \pm 0.2^{\mathrm{a}}$ & $29.0 \pm 0.2^{b}$ \\
\hline Carcass width (cm) & $25.3 \pm 0.3^{\mathrm{a}}$ & $26.8 \pm 0.2^{b}$ & $27.6 \pm 0.3^{\text {a }}$ & $24.5 \pm 0.2^{b}$ \\
\hline Leg length $(\mathrm{cm})$ & $28.1 \pm 0.2^{\mathrm{a}}$ & $27.0 \pm 0.2^{b}$ & $28.3 \pm 0.2^{\mathrm{a}}$ & $26.9 \pm 0.2^{b}$ \\
\hline Leg circumference (1) (cm) & $43.1 \pm 0.4$ & $44.1 \pm 0.4$ & $46.0 \pm 0.4^{\mathrm{a}}$ & $41.1 \pm 0.4^{\mathrm{b}}$ \\
\hline Leg circumference $(2)(\mathrm{cm})$ & $28.1 \pm 0.3$ & $28.2 \pm 0.2$ & $28.8 \pm 0.3^{\text {a }}$ & $27.4 \pm 0.3^{b}$ \\
\hline Eye muscle area $\left(\mathrm{cm}^{2}\right)$ & $13.0 \pm 0.4^{\mathrm{a}}$ & $15.1 \pm 0.3^{b}$ & $15.8 \pm 0.4^{\mathrm{a}}$ & $12.3 \pm 0.3^{b}$ \\
\hline Fat depth (mm) & $1.20 \pm 0.11^{\mathrm{a}}$ & $1.62 \pm 0.09^{b}$ & $1.50 \pm 0.11$ & $1.31 \pm 0.09$ \\
\hline \multicolumn{5}{|l|}{ Organs } \\
\hline Kidney (kg) & $0.16 \pm 0.003^{\mathrm{a}}$ & $0.15 \pm 0.02^{b}$ & $0.19 \pm 0.03^{\mathrm{a}}$ & $0.12 \pm 0.02^{b}$ \\
\hline Heart (kg) & $0.29 \pm 0.01$ & $0.29 \pm 0.01$ & $0.34 \pm 0.01^{\mathrm{a}}$ & $0.24 \pm 0.01^{b}$ \\
\hline Liver (kg) & $0.99 \pm 0.02^{\mathrm{c}}$ & $1.13 \pm 0.02^{\mathrm{d}}$ & $1.37 \pm 0.02^{\mathrm{a}}$ & $0.75 \pm 0.02^{b}$ \\
\hline Lungs (kg) & $0.81 \pm 0.01$ & $0.85 \pm 0.01$ & $1.00 \pm 0.01^{\mathrm{a}}$ & $0.65 \pm 0.01^{b}$ \\
\hline Spleen (kg) & $0.09 \pm 0.003$ & $0.10 \pm 0.003$ & $0.12 \pm 0.003^{\mathrm{a}}$ & $0.07 \pm 0.003^{b}$ \\
\hline Kidney fat (kg) & $0.23 \pm 0.03^{c}$ & $0.29 \pm 0.02^{\mathrm{d}}$ & $0.27 \pm 0.02$ & $0.25 \pm 0.02$ \\
\hline \multicolumn{5}{|l|}{ Retail cuts } \\
\hline Neck (kg) & $1.07 \pm 0.02$ & $1.06 \pm 0.02$ & $1.28 \pm 0.02^{\mathrm{a}}$ & $0.86 \pm 0.02^{b}$ \\
\hline Shoulder (kg) & $3.76 \pm 0.10^{\mathrm{c}}$ & $4.25 \pm 0.08^{\mathrm{d}}$ & $4.80 \pm 0.10^{\mathrm{a}}$ & $3.20 \pm 0.08^{b}$ \\
\hline Chuck (kg) & $3.68 \pm 0.09$ & $3.82 \pm 0.07$ & $4.24 \pm 0.08^{\mathrm{a}}$ & $3.26 \pm 0.07^{b}$ \\
\hline Flat rib (kg) & $2.43 \pm 0.09^{c}$ & $2.92 \pm 0.08^{\mathrm{d}}$ & $3.38 \pm 0.09^{a}$ & $1.97 \pm 0.08^{b}$ \\
\hline Prime rib (kg) & $1.78 \pm 0.07$ & $2.01 \pm 0.05$ & $2.39 \pm 0.07^{\mathrm{a}}$ & $1.41 \pm 0.06^{\mathrm{b}}$ \\
\hline Loin $(\mathrm{kg})$ & $2.35 \pm 0.08^{c}$ & $2.72 \pm 0.06^{\mathrm{d}}$ & $3.02 \pm 0.08^{a}$ & $2.05 \pm 0.07^{b}$ \\
\hline Hindquarters (kg) & $7.09 \pm 0.14$ & $7.27 \pm 0.11$ & $8.17 \pm 0.14^{\mathrm{a}}$ & $6.2 \pm 0.12^{b}$ \\
\hline
\end{tabular}

${ }^{\mathrm{ab}}$ Row means with different superscripts differ significantly $(\mathrm{P}<0.01)$

${ }^{\text {cd }}$ Row means with different superscripts differ significantly $(\mathrm{P}<0.05)$

Table 2 Least square means ( \pm s.e.) for the proximate chemical composition of the $M$. longissimus thoracis from the $11 / 13^{\text {th }}$-rib cut for the main effects of breed (SAMM vs. Dormer) and sex (ram vs. ewe)

\begin{tabular}{|c|c|c|c|c|}
\hline \multirow[t]{2}{*}{ Chemical } & \multicolumn{2}{|c|}{ Breed } & \multicolumn{2}{|c|}{ Sex } \\
\hline & $\begin{array}{l}\text { SAMM } \\
(\mathrm{n}=12)\end{array}$ & $\begin{array}{l}\text { Dormer } \\
(\mathrm{n}=12)\end{array}$ & $\begin{array}{c}\text { Ram } \\
(\mathrm{n}=12)\end{array}$ & $\begin{array}{c}\text { Ewes } \\
(\mathrm{n}=12)\end{array}$ \\
\hline Moisture & $74.1 \pm 0.2$ & $74.3 \pm 0.3$ & $74.5 \pm 0.2$ & $73.9 \pm 0.2$ \\
\hline Protein & $22.2 \pm 0.2$ & $21.9 \pm 0.2$ & $21.7 \pm 0.2^{c}$ & $22.4 \pm 0.2^{\mathrm{d}}$ \\
\hline Lipid & $3.33 \pm 0.20$ & $3.14 \pm 0.21$ & $2.86 \pm 0.21^{\mathrm{c}}$ & $3.61 \pm 0.21^{d}$ \\
\hline Ash & $1.22 \pm 0.01$ & $1.19 \pm 0.01$ & $1.17 \pm 0.01^{\mathrm{a}}$ & $1.24 \pm 0.01^{b}$ \\
\hline
\end{tabular}

${ }^{\mathrm{ab}}$ Row means with different superscripts differ significantly $(\mathrm{P}<0.01)$

${ }^{\text {cd }}$ Row means with different superscripts differ significantly $(\mathrm{P}<0.05)$ 
Table 3 Means ( \pm s.e.) for the fatty acid profile of the $M$. longissimus thoracis from the $11 / 13^{\text {th }}$-rib cut for the main effects of breed (SAMM vs. Dormer) and sex (ram vs. ewe). Values are expressed as \% of identified fatty acids

\begin{tabular}{|c|c|c|c|c|}
\hline \multirow[b]{2}{*}{ Fatty acid } & \multicolumn{2}{|c|}{ Breed } & \multicolumn{2}{|c|}{ Sex } \\
\hline & $\begin{array}{l}\text { SAMM } \\
(\mathrm{n}=12) \\
\end{array}$ & $\begin{array}{l}\text { Dormer } \\
(\mathrm{n}=12)\end{array}$ & $\begin{array}{c}\text { Ram } \\
(\mathrm{n}=12)\end{array}$ & $\begin{array}{c}\text { Ewes } \\
(\mathrm{n}=12)\end{array}$ \\
\hline C14:0 & $1.52 \pm 0.12^{\mathrm{a}}$ & $2.12 \pm 0.12^{b}$ & $1.75 \pm 0.12$ & $1.89 \pm 0.13$ \\
\hline C16:0 & $24.3 \pm 0.8$ & $26.1 \pm 0.8$ & $25.5 \pm 0.8$ & $24.9 \pm 0.8$ \\
\hline C18:0 & $23.6 \pm 0.9$ & $23.9 \pm 0.8$ & $23.6 \pm 0.8$ & $23.9 \pm 0.9$ \\
\hline C20:0 & $0.04 \pm 0.03^{\mathrm{a}}$ & $0.15 \pm 0.03^{b}$ & $0.06 \pm 0.03$ & $0.13 \pm 0.04$ \\
\hline $\mathrm{C} 22: 0$ & $0.01 \pm 0.01$ & $0.02 \pm 0.01$ & $0.01 \pm 0.01$ & $0.02 \pm 0.01$ \\
\hline C24:0 & $0.03 \pm 0.02$ & $0.03 \pm 0.02$ & $0.28 \pm 0.2$ & $0.05 \pm 0.2$ \\
\hline SFA $^{1}$ & $49.5 \pm 1.0^{\mathrm{a}}$ & $52.8 \pm 0.9^{b}$ & $51.2 \pm 1.0$ & $50.9 \pm 1.0$ \\
\hline C16:1n7 & $1.30 \pm 0.10$ & $1.35 \pm 0.10$ & $1.42 \pm 0.10$ & $1.24 \pm 0.10$ \\
\hline C18:1n9 & $36.5 \pm 1.0^{\mathrm{c}}$ & $33.9 \pm 0.9^{d}$ & $34.9 \pm 0.8$ & $34.5 \pm 0.9$ \\
\hline C20:1n9 & $0.02 \pm 0.02$ & $0.05 \pm 0.01$ & $0.017 \pm 0.01$ & $0.06 \pm 0.02$ \\
\hline C24:1n9 & $0.03 \pm 0.01$ & $0.02 \pm 0.01$ & $0.02 \pm 0.01$ & $0.03 \pm 0.01$ \\
\hline MUFA $^{2}$ & $37.9 \pm 0.9^{\mathrm{c}}$ & $35.3 \pm 0.9^{d}$ & $36.3 \pm 0.9$ & $36.8 \pm 0.9$ \\
\hline C18:2n6 & $4.59 \pm 0.21^{\mathrm{a}}$ & $4.13 \pm 0.20^{b}$ & $4.69 \pm 0.2$ & $4.04 \pm 0.21$ \\
\hline C18:3n6 & $0.19 \pm 0.08$ & $0.19 \pm 0.08$ & $0.15 \pm 0.08$ & $0.22 \pm 0.08$ \\
\hline C18:3n3 & $1.76 \pm 0.23$ & $1.42 \pm 0.22$ & $2.00 \pm 0.21^{\mathrm{c}}$ & $1.18 \pm 0.23^{d}$ \\
\hline C20:2n6 & $0.17 \pm 0.03^{a}$ & $0.06 \pm 0.03^{b}$ & $0.13 \pm 0.03$ & $0.10 \pm 0.03$ \\
\hline C20:3n6 & $1.30 \pm 0.35$ & $1.57 \pm 0.34$ & $1.82 \pm 0.35$ & $1.06 \pm 0.36$ \\
\hline C20:4n6 & $1.03 \pm 0.07$ & $0.94 \pm 0.07$ & $1.02 \pm 0.07$ & $0.95 \pm 0.07$ \\
\hline C20:3n3 & $0.19 \pm 0.05$ & $0.15 \pm 0.05$ & $0.12 \pm 0.04$ & $0.22 \pm 0.05$ \\
\hline C20:5n3 & $0.64 \pm 0.07$ & $0.60 \pm 0.06$ & $0.68 \pm 0.06$ & $0.56 \pm 0.07$ \\
\hline C22:2n6 & $0.28 \pm 0.11$ & $0.40 \pm 0.11$ & $0.22 \pm 0.11$ & $0.46 \pm 0.12$ \\
\hline $\mathrm{C} 22: 4 \mathrm{n} 6$ & $0.54 \pm 0.13^{c}$ & $0.21 \pm 0.13^{d}$ & $0.35 \pm 0.12$ & $0.40 \pm 0.13$ \\
\hline C22:5n3 & $0.57 \pm 0.04$ & $0.51 \pm 0.04$ & $0.56 \pm 0.04$ & $0.52 \pm 0.04$ \\
\hline C22:6n3 & $0.24 \pm 0.02$ & $0.25 \pm 0.02$ & $0.22 \pm 0.02$ & $0.27 \pm 0.02$ \\
\hline PUFA $^{3}$ & $11.2 \pm 0.6$ & $10.4 \pm 0.5$ & $11.97 \pm 0.53$ & $9.98 \pm 0.57$ \\
\hline PUFA:SFA ${ }^{4}$ & $0.23 \pm 0.01^{\mathrm{a}}$ & $0.20 \pm 0.01^{\mathrm{a}}$ & $0.24 \pm 0.01^{\mathrm{a}}$ & $0.20 \pm 01^{\mathrm{a}}$ \\
\hline DFA $^{5}$ & $0.32 \pm 0.04$ & $0.26 \pm 0.04$ & $0.27 \pm 0.04$ & $0.31 \pm 0.04$ \\
\hline (C:18:0+C18: & & & & \\
\hline 1n9):C16:0 & $2.52 \pm 0.12$ & $2.29 \pm 0.11$ & $2.37 \pm 0.0 .11$ & $2.44 \pm 0.12$ \\
\hline
\end{tabular}

${ }^{\mathrm{ab}}$ Row means with different superscripts differ significantly $(\mathrm{P}<0.01)$

${ }^{\text {cd }}$ Row means with different superscripts differ significantly $(\mathrm{P}<0.05)$

${ }^{1}$ SFA = Saturated fatty acids

${ }^{2}$ MUFA $=$ Mono-unsaturated fatty acids

${ }^{3}$ PUFA $=$ Polyunsaturated fatty acids

${ }^{4}$ PUFA: SFA = Polyunsaturated fatty acids to saturated fatty acids ratio

${ }^{5} \mathrm{DFA}=$ Desirable fatty acids

\section{Discussion}

The higher live weight of the rams at slaughter could be attributed to the traditional difference in growth rate and mature size between ewes and rams (Kirton et al., 1995). The fact that rams were fed concentrates during preparation for breed inspection, however, also contributed to this difference. This contention is supported by the fact that fat depth was similar for rams and ewes. Ewes are generally expected to be fatter than rams at the same level of husbandry care (Jeremiah et al., 1997). The higher carcass weight of the rams was a direct result of their higher live weight. Stomach content and skin weight can affect dressing percentage when the live weights are recorded (Kirton et al., 1995).

All the carcass component weights, organ weights, retail cut weights and eye-muscle areas were generally higher in rams than in ewes. These differences were most probably associated with the higher slaughter weight of the rams.

The heavier skin weights of the SAMM sheep could also have contributed to their dressing percentages being significantly lower than that of Dormers (Table 1). The significant lower dressing 
percentage of SAMM sheep could be the reason why their carcass weights were significant lower (Table 1). The heavier skins of the SAMM sheep could be attributed to the fact that all the sheep were not shorn on the same date. The Dormers had shorter wool and thus a lower skin weight. The longer carcasses and hind leg length with the narrower carcasses of the SAMM are an indication that the conformation of SAMM sheep was rankier than that of the Dormers.

According to Lawrie (1998), early-maturing sheep breeds tend to gain fat readily, accounting for the fact that Dormers had more kidney fat and a greater fat depth than SAMM sheep at the same age. Even though the live weights did not differ between the breeds (Table 1), the Dormer had an advantage of almost two kilograms. Apart from the neck where breed differences were negligible, the constant difference in favour of Dormers merely accounted for the difference of approximately two kilograms in carcass weight.

There were no differences in the proximate chemical analyses between the two breeds, but the values obtained for the SAMM breed were similar to those found in the literature (Sheridan, 2001). The differences in proximate chemical analysis derived from meat from rams and ewes were correspondingly similar to that reported in the literature (Teixeira et al., 1996).

The two most prominent SFA in SAMM meat, palmitic acid (C16:0) and stearic acid (C18:0), were consistent with results reported by Webb et al., (1997) for SAMM wethers. The higher MUFA content of SAMM meat probably resulted from the generally fatter carcasses of Dormers (Table 1). Therefore, the relationship between cell wall and cell content of the adipose tissue was possibly greater in SAMM meat. Cell walls comprise mainly of unsaturated fatty acids, which explains the higher MUFA concentration of the meat from SAMM sheep (Rowe et al., 1999). Both the DFA and PUFA:SFA ratios are indications of the potential health benefits of the beneficial fatty acids to humans (Rhee, 1992; Warris, 2000). The ratios of PUFA:SFA for Dormers and SAMM sheep were above the values below 0.15, reported by Hoffman et al. (2003a, b) for crossbred lambs and Merinos, respectively, but still far below the recommended ratio of 0.45 for human intake in the United Kingdom (Warris, 2000). In a previous report on SAMM wethers, Webb \& Casey (1995) correspondingly reported a mean PUFA:SFA ratio of 0.22 at $43 \mathrm{~kg}$ slaughter weight. The means from the present study also accorded with means reported for other bovine and ovine meats (Geay et al., 2001). The higher PUFA:SFA ratio of the SAMM breed suggests that this meat is possibly healthier for human consumption. The same reasoning applied as far as rams were concerned. Similarly, the ratio of (C18:0+C18:1n9):C16:0 indicates the possible health effects of the lipids (Grundy, 1997; Banskalievaa et al., 2000). High dietary levels of SFA increase human plasma cholesterol concentrations compared with high levels of MUFA (Grundy \& Denke, 1990). Not all SFA have equivalent effects, for example mysteric (C14:0) acid may raise plasma cholesterol levels (Denke \& Grundy, 1992). In this investigation the values were very similar between the two breeds and between sexes.

\section{Conclusion}

Conclusions were in accordance with the original production objectives of the breeds. The SAMM (a dual-purpose sheep breed) is suitable for the commercial production of meat and wool whilst the Dormer is used as a sire breed for terminal crossbreeding to enhance the meat production potential of the dam breed in the crossbred progeny. The higher retail cut weights of the Dormer sheep and higher skin, head and trotter weights in SAMM sheep are important observations indicating the superiority of the Dormer over the SAMM in meat production. From an eating prospective the meat from SAMM sheep could be considered to be slightly healthier for human consumption. Further investigations should compare the eating quality of the meat from the two breeds.

\section{Acknowledgement}

We wish to thank the personnel of Tommi's abattoir for their friendly co-operation. This research was partly funded by grants from the Technology and Human Resources for Industry Programme (THRIP) and from the National Research Foundation (NRF) of South Africa. Their involvement is gratefully acknowledged.

\section{Reference}

ALASA, 1995. Official methods of analysis (16th ed.). Association of Official Analytical Chemists. AOAC International, Maryland, USA. Method 4.5.01 (920.39). 
Banskalievaa, V., Sahlu, T. \& Goetsch, A.L., 2000. Fatty acid composition of goat muscles and fat deposits: a review. Small Rumin. Res. 37, 255-268.

Casey, N.H., 1982. Carcass and growth characteristics of four South African sheep breeds and the Boer goat. DSc (Agric) thesis, University of Pretoria, South Africa.

Denke, M.A. \& Grundy, S.M., 1992. Comparison of effects of lauric acid and palmitic acid on plasma lipids. Am. J. Clin. Nutr. 56, 895-898.

Enright, W.J., Quirke, J.F., Gluckman, P.D., Breier, B.H., Kennedy, L.G., Hart, I.C., Roche, J.F., Coert, A. \& Allen, P., 1990. Effects of long-term administration of pituitary-derived bovine growth hormone and estradiol on growth in steer. J. Anim. Sci. 68, 2345-2352.

Fahmy, M.H., Gariepy, C. \& Fortin, J., 1999. Carcass quality of crossbred lambs expressing the callipyge phenotype born to Romanov purebred and crossbred ewes. Anim. Sci. 69, 525- 533.

Geay, Y., Boauchart, D., Hocquette, J. \& Culiole, J., 2001. Effect of nutritional factors on biochemical, structural and metabolic characteristics of muscles in ruminants, consequences on dietic value and sensorial qualities of meat. Rumin. Nutr. Meat Qual. 41, 1-26.

Gilmour, A.R., Luff, A.F., Fogarty, N.M. \& Banks, R., 1994. Genetic parameters for ultrasonic fat depth and eye muscle measurements in live Poll Dorset sheep. Aust. J. Agric. Res. 45, 1281-1291.

Gilmour, A.R., Cullis, J.J., Welham, S.J. \& Thompson, R., 1999. ASREML-Reference manual. NSW Agriculture Biometric Bulletin No. 3. NSW Agriculture Institute, Forest Road, Orange 2800, NSW, Australia.

Grundy, S.M., 1997. What is the desirable ratio of saturated, polyunsaturated and monounsaturated fatty acid in the diet? Amer. J. Clin. Nutr. 66, S988-S990.

Grundy, S.M. \& Denke, M.A., 1990. Dietary influences on serum lipids. J. Lipid Res. 31, 1149-1172.

Hoffman, L.C., 2000. The yield and carcass chemical composition of impala (Aepyceros melampus), a Southern African antelope species. J. Sci. Food Agric. 80, 752-756.

Hoffman, L.C., Muller, M., Cloete, S.W.P. \& Schmidt, 2003a. Comparison of six crossbred lamb types: sensory, physical and nutritional meat quality characteristics. Meat Sci. 65, 1265-1274.

Hoffman, L.C., Schmidt, D., Muller, M.M., Cloete, J.J.E. \& Cloete, S.W.P., 2003b. Sensory and objective mutton quality characteristics of SA Merino sheep selected for and against reproductive fitness. S. Afr. J. Anim. Sci. 33, 52-64.

Hopkins, D.L., Gilbert, K.D., Pirlot, K.L. \& Roberts, A.H.K., 1992. Elliottdale and crossbred lambs: growth rate, wool production, fat depth, saleable meat yield, carcass composition and muscle content of selected cuts. Aust. J. Exp. Agric. Res. 32, 429-434.

Jeremiah, L.E., Jones, S.D.M., Tong, A.K.W., Robertson, W.M. \& Gibson, L.L., 1997. The influence of lamb chronological age, slaughter weight and gender on yield and cutability. Int Sheep Goat Res. J. 13, 39-46.

Kirton, A.H., Carter, A.H., Clarke, J.N., Sinclair, D.P., Mercer, G.J.K. \& Duganzich, D.M., 1995. A comparison between 15 ram breeds for export lamb production 1. Liveweights, body composition, carcass measurements and composition. N. Z. J. Agric. Res. 38, 347-360.

Lawrie, R.A., 1998. Lawrie’s Meat Science. Sixth Edition. Woodhead Publishing Limited, Cambridge, England.

Morrison, W.R. \& Smith, M.L., 1964. Preparation of fatty acid methyl esters and dimethylacetals from lipids with boron fluoride-methanol. J. Lipid Res. 5, 600-602.

Neser, F.W.C., Erasmus, G.J. \& Van Wyk, J.B., 2000. Genetic studies on the South African Mutton Merino: growth traits. S. Afr. J. Anim. Sci. 30, 172-177.

Oman, J.S., Waldron, D.F., Griffin, D.B. \& Savell, J.W., 1999. Effects of breed-type and feeding regimen on goat carcass traits. J. Anim. Sci. 77, 3215-3218.

Purchas, R.W., 1978. Some effects of nutrition and castration on meat production from male Suffolk cross (Border Leicester-Romney cross) lambs. 1. Growth and carcass quality. N. Z. J. Agric. Res. 21, 370376.

Rhee, K.S., 1992. Fatty acids in meat and meat products. In: Fatty acids in foods and their health implications. Ed. Chow, C.K., Marcel Dekker Inc., New York.

Rowe, A., Macedo, F.A.F., Visetainer, J.V., Souza N.E. \& Matsushita, M., 1999. Muscle composition and fatty acid profile in lambs fattened in drylot or pasture. Meat Sci. 51, 283-288.

Sheridan, R., 2001. A comparative analysis of nutrient utilisation and meat quality parameters of Boer goats and South African Mutton Merinos. MSc thesis, University of Stellenbosch, South Africa. 
Stanford, K., Woloschuk, C.M., McClelland, L.A., Jones, S.D.M. \& Price, M.A., 1997. Comparison of objective external carcass scores for prediction of lamb carcass quality. Can. J. Anim. Sci. 77, 217223.

Teixeira, A., Delfa, R. \& Treacher, T., 1996. Carcass composition and body fat depots of Galego Bragnançano and crossbred lambs by Suffolk and Merino Precoce sire breeds. Anim. Sci. 63, 389394.

Thonney, M.L., Taylor, St-C.S., Murry, J.I. \& McClelland, T.H., 1987. Breed and sex differences in equally mature sheep and goats. 3. Muscle weight distribution. Anim. Prod. 45, 277-290.

Van der Merwe, C.A., 1976. Genetiese en nie-genetiese faktore wat die produksie en reproduksie eienskappe van die Elsenburg Dormer skaapkudde beïnvloed. PhD (Agric) thesis, University of Stellenbosch, South Africa.

Van Wyk, J.B., Erasmus, G.J. \& Konstantinov, K.V., 1993. Non-genetic factors influencing early growth traits in the Elsenburg Dormer sheep stud. J. Anim. Sci. 23, 67-71.

Warris, P.D., 2000. Meat Science: An Introductory Text. CABI Publishing, New York.

Webb, E.C. \& Casey, N.H., 1995. Genetic differences in fatty acid composition of subcutaneous adipose tissue in Dorper and SA Mutton Merino wethers at different live weights. Small Rumin. Res. 18, 8188.

Webb, E.C., Bosman, M.J.C. \& Casey, N.H., 1997. Influence of dietary presentation on the composition of fatty acids and sensory characteristics of meat from wethers. S. Afr. J. Food Sci. Nutr. 9, 69-76. 